単結晶構造解析分野における中性子と $\mathbf{X}$ 線回折手法の相補的利用

野田幸男，木村宏之，鬼柳亮嗣，小宮山聡

（東北大学多元物質科学研究所）

\title{
Complementary studies of neutron- and X-ray-diffraction methods on a single crystal structure analysis
}

Yukio Noda, Hiroyuki Kimura, Ryoji Kiyanagi, Satoshi, Komiyama

Institute of Multidisciplinary Research for Advanced Materials, Tohoku University

\section{0}

1 はじめに

単結晶を使用した構造解析は, 色々な意味で大 変わかりやすく, また, 少ない仮定で非常に微細 なところまで議論できる特徴がある。もちろん， 通常は実験室のX 線回折装置が使用されている. 最近では粉末回折法の進歩により, 多くの場合, 単結晶ができなくても構造解析が可能となってき た。ある意味では,「単結晶法と粉末法」の「競争 の時代」といえるかもしれない，また，「X線回折 と中性子回折」は, 原子炬やパルスの中性子源や 回折装置の発達と, 放射光や実験室の装置の発達 とが，やはり「競争の時代」となっている．しか しながら，それぞれの方法をちやんと理解してい る人は，互いに得意なところをうまく使い分けて 「相補的」に利用している。

結晶構造解析や磁気構造解析に中性子実験が多 大な威力を発揮することは，ここでは多くを述べ る必要もないと思う。磁気構造解析に対しては, 最近では放射光を利用した磁気散乱も使用可能だ が, 通常の実験範囲では中性子の方が圧倒的に有 利である. それでは, 結晶構造解析において中性 子の果たすべき役割は何であろうか. まず考えら れるのは，X線では実験できないので中性子を使 う場合である。例えば， Mn, $\mathrm{Fe} ， \mathrm{Co}$ などの合金 では，X 線でこれらを区別するのは大変に難しい が，中性子では簡単である。また，重い金属の中 にある軽い水素原子などはX線で見るのは大変難 しいが，中性子ではもっとも得意とするところで ある. 一方, 中性子の吸収断面積が非常に大きく ほとんど実験にならない元素もある. 例えば, $\mathrm{Cd}$, $\mathrm{Gd}, \mathrm{Sm}$ 等々である.これらの元素は, X 線回折で はそれ程大きな問題にはならないので，構造解析 可能である.これらは，「X 線と中性子の不得手な ところと得意なところを相補いあう使い方 相補 的使用法」である。もちろん，この場合は，「相 補的」といっても，X 線や中性子の技術が進歩す るにつれて困難さが軽减され，今まで測定できな かったものが測定可能となって，「相補的」でなく なる可能性もある。例えば X 線異常散乱により, $\mathrm{Mn}, \mathrm{Fe}, \mathrm{Co}$ にX 線回折で大きなコントラストを
付けることも可能である，逆に，高エネルギーの 熱外中性子を使うと今まで吸収のために実験でき なかった Sm などの元素でも実験可能となる。 そ ういう意味で, ここで使う「相補的」という言葉 は，現時点での技術的未熟さを互いにカバーする ということで使われていると理解してもよいと思 われる。もちろん，現実的にはこのような相補的

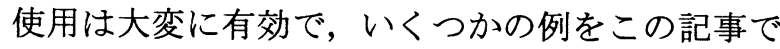
も紹介することとする.

最近では，上記のような狭い意味の「相補的」 だけでなく，もっと積極的に，同じ対象をX線と 中性子で見てそれぞれから得られる情報を使い， さらに深い理解を得る使い方ができるようになっ てきた，その例として，中性子で原子核の分布を 詳細に調べ， $\mathrm{X}$ 線でその原子核周りの電子雲の分 布を詳細に調べて, 物性の異常と原子の量子力学 的な構造状態を関連づける研究である.この場合 は,「相補的」と言っても, どちらの手法も必要で, 両方の特性を利用している。この時に大事なこと は，散乱している実体が，X 線と中性子で違うこ とをきっちりと認識することである.

いくつかの物資での散乱振幅（中性子の散乱振 幅 $b, \mathrm{X}$ 線のトムソン散乱に対する原子形状因子 では全電子数 Z) を表 1 に示す．表では，中性子 に対する吸収断面積（散乱断面積 $\sigma_{\mathrm{s}}$ と $\sigma_{\mathrm{a}}$ ）も示 している.

まず，中性子で特徴的なことは，散乱振幅に負 の值があることである.これは，入射した波の位

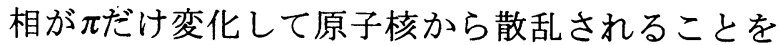
意味している．散乱振幅の大きさは，原子核との 相互作用によるから，原子番号には比例していな いし，同じ原子でも同位元素で違う。例えば，水 素原子の H では散乱振幅が負で非干渉性非弾性散 乱のため大きな $\sigma_{\mathrm{s}}$ の值を持つ.一方, 同じ水素原 子の D の散乱振幅は正で吸収もほとんどない。こ のことは, 水素原子を含んだ物質での構造解析で, D と H を区別できることを示しており，マーカー として利用することも可能である. 実用的な材料 物質である $\mathrm{Mn}, \mathrm{Fe}, \mathrm{Co}$ の原子番号は非常に近い ので，X 線回折では異常散乱を使わないと区別が 


\begin{tabular}{|lllll|}
\hline & $Z$ & $b\left(10^{-13} \mathrm{~cm}\right)$ & $\sigma_{\mathrm{s}}$ & $\sigma_{\mathrm{a}}(1.08 \AA)$ \\
${ }^{1} \mathrm{H}$ & 1 & -3.79 & 81.7 & 0.19 \\
${ }^{2} \mathrm{H}$ & 1 & 6.672 & 7.63 & $5.3 \times 10^{-4}$ \\
$\mathrm{~B}$ & 5 & $5.4+0.21 \mathrm{i}$ & 4.3 & 759 \\
${ }^{11} \mathrm{~B}$ & 5 & 6.1 & 4.6 & - \\
$\mathrm{C}$ & 6 & 6.657 & 5.57 & 0.0034 \\
$\mathrm{~N}$ & 7 & 9.38 & 12.2 & 1.85 \\
$\mathrm{Mn}$ & 25 & -3.70 & 2.2 & 13.3 \\
$\mathrm{Fe}$ & 26 & 9.51 & 11.8 & 2.55 \\
$\mathrm{Co}$ & 27 & 2.78 & 6.9 & 37.2 \\
$\mathrm{Cd}$ & 48 & $3.7+1.6 \mathrm{i}$ & 5.7 & 2450 \\
$\mathrm{~Pb}$ & 82 & 9.42 & 11.5 & 0.17 \\
\multicolumn{2}{l}{ 表 1 } & 原子番号 $Z$ と中性子の散乱振幅と吸収の例 \\
\hline
\end{tabular}

難しいが，中性子だと散乱振幅が大きく違ってい てコントラストが非常に明確につく.別の例では, $\mathrm{PbH}_{2}$ のような（こんな物質はないが）極端に原子 番号の違う物質の構造でも, 中性子の散乱振幅の 違いは適当で，かつ $\mathrm{Pb}$ の吸収もそれほど大きく ないので構造解析可能である. 一方, $\mathrm{Cd}$ や B ように，中性子に対する吸収が非常に大きな物で は同位元素に置換するなどの工夫が必要だし， $\mathrm{CD}_{4}$ のような分子だと $\mathrm{C}$ と D でのコントラストは ほとんどつかない。つまり，中性子が万能という わけではなく，原子により得手不得手があるとい うことである.なお，今回は中性子から眺めた「相 補性」を議論しているが，放射光学会誌に「放射 光と中性子 相補性, 競争そして共創へ」とい う記事も書いたので ${ }^{1)}$ ，そちらも参照してもらい たい.

\section{2 中性子 4 軸回折装置 FONDER の性能}

単結晶で構造解析の実験をするには写真法や 4 軸回折計が使われる。ともに，単結晶の方位の情 報を何らかの方法で記録して逆格子の位置を一義 的に求めることに特徵がある。この記事では，原 研東海の 3 号炉に設置して最近稼働し始めた FONDER という中性子 4 軸回折装置を紹介する. 日本に中性子で単結晶構造解析できるのが KUR だけであったこともあり，物性研がもっていたビ ームポートT22に是非 4 軸回折装置をつけたいと 科研費を申請して認められたものである。この装 置の詳しい紹介記事はすでに「波紋」や論文に出 ていまるので，そちらを参照してもらいたい ${ }^{2,3)}$. ここでは, 装置の特徵と衫らいだけを述べること にとどめておく

中性子の実験は，X 線の実験をやっている人か ら見ると大変におおざっぱに見える. 結晶を回折 計の上に置いてセンタリングするのは目測だけで, クライオスタットに入っていればそれさえも行わ ない，それでいて，様々な逆格子点はそこそこの 精度ででてくる. しかしながら, 強度の絶対值は あまり議論せずに，たいていは個別の反射それぞ れに対してスケール因子でごまかしてしまう。 そ れに対して，構造解析を行うときには，あらゆる
ことが絶対値での勝負となる. 4 軸回折装置では, 散乱角の $2 \theta$ 以外に, 結晶の方位を指定する $\omega, \chi$, $\phi$ という 3 つの角度を使う。このうち， $2 \theta ， \omega ， \chi$ の絶対值を常に保証する必要がある．そのことに より, 単位砲の格子定数の絶対值がもとまるし, 測定強度の信頼度も上がる. また, 結晶は常に上 記の 4 軸の交差点に存在する必要がある. そのた めに, FONDER では望遠鏡を使用して結晶を $0.1 \mathrm{~mm}$ 程度の精度で回転中心に設置するようにし ている.この作業は, 中性子だけを行っている人 から見ると驚異的に精密なことをやっているよう に見られるが, 放射光での実験では $1 \mu \mathrm{m}$ の精度で センタリングを行うから, やはりまだまだ大雑把 ともいえる.

格子定数がどの程度決まるかの例を以下に示す. ごく最近の実験例として, 物性研の阿兽氏の $\mathrm{Sr}_{3} \mathrm{Ru}_{2} \mathrm{O}_{7}$ で得られたものである. 24 個のブラッグ 反射の 4 軸角を自動的に求めて, $a, b, c, \alpha, \beta, \gamma$ 何の 制限も付け加えないで決定したものである.

$$
\begin{aligned}
& a=5.4984(8), b=5.4977(3), c=20.732(1) \AA \\
& \alpha=90.004(5), \beta=89.993(8), \gamma=90.003(7) \\
& \lambda=1.54070 \AA
\end{aligned}
$$

この值が何を意味しているかはここでは議論しな いが，FONDER の精度としては，角度が $90^{\circ}$ から $0.2^{\circ}$ ずれて $90.20^{\circ}$ などとなれば，「単位胞は単斜晶 系以下に落ちている」などと断言できる.

次に, FONDER が何をねらった装置かを説明す る. それが，「相補的」ということを理解していた だく早道だし, 単結晶中性子構造解析の意義も理 解していただけると思う. 現在ねらっていること は以下のように列挙することができる.

1）無機物や有機物の中の水素の原子核を見る.

2）重い原子を含んだ酸化物中の酸素原子の微小 変位を見る。

3）複雑な磁気構造を決定する.

4）磁気構造解析によりスピンを担っている電子 の分布を見る。

5）磁気散漫散乱を測定する.

個人的な興味の対象として「構造相転移」と「物 質の機能の発現に対する構造の役割の解明 構造 物性」があるが, もちろん, FONDER は構造相転 移しない物質でもどんどん使ってもらっている.

\section{3 構造解析の例}

ここでは，FONDERを使用したいくつかの測定 例を示す．まず，一番簡単な例として $\mathrm{NaCl}$ の構 造解析の結果を図 1 に示寸. この例は, 中性子夏 の学校や若手の学校での実習で行ったもので 1 時 間程度の測定結果である. 反射点が 52 でパラメー タはスケール因子と消衰効果のパラメータ，およ び温度因子のみである. $B(\mathrm{Na})=1.72, B(\mathrm{Cl})=1.34$ で信頼度因子は $R=0.68 \%$ となった。図の横軸は計 


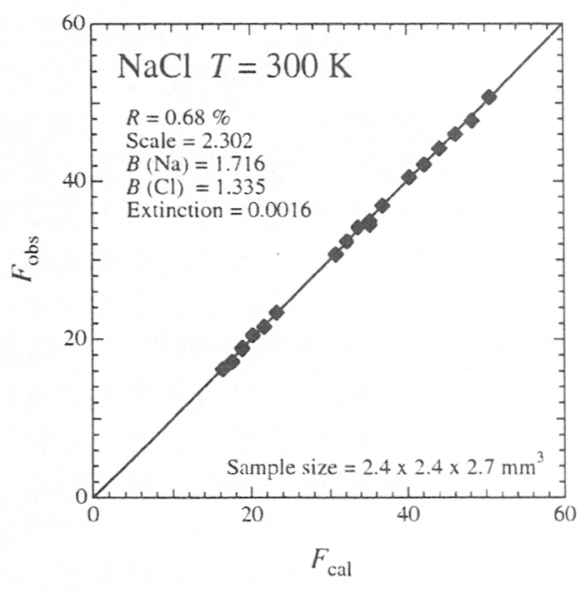

図 $1 \mathrm{NaCl}$ の構造解析の例で $F_{\mathrm{cal}}$ と $F_{\mathrm{obs}}$ の比較.

算で得られた構造因子の絶対値 $\left|F_{\text {cal }}\right|$, 縦軸は種々 の補正を施した構造因子の測定值 $\left|F_{\mathrm{obs}}\right|$ である。斜 め $45^{\circ}$ の直線は完全な構造解析に対応する。構造 解析の結果は, ほぼこの直線の上に乗っている。 この試料は，実習でも簡単に解析できるように， 液体窒素に何度も漬けて消衰効果を取り除いてい る. $\mathrm{NaCl}$ の構造解析は極端に簡単な例であるが， それでもちゃんと解析できるようになるにはかな りの月日が必要であった。 それは, 装置の信頼度 だけでなく, 解析を行うためのノウハウの蓄積も 必要だったためである.

次に示すのは, 逆に極端に複雑な場合で, 北里 大学の菅原グループの実験結果である ${ }^{4)}$. 物質は DNAの材料ともなるヌクレオチドで, 湿気を吸っ たり吐いたりして一次相転移を行う物質 $\left(\mathrm{C}_{10} \mathrm{H}_{26} \mathrm{~N}_{4} \mathrm{O}_{15.5} \mathrm{PNa}_{2}\right)$ である. 格子定数は $a=8.697$, $b=23.208, c=21.975$ で $C 222_{1}$ である。測定には 10 日間程度要している。構造解析は, パラメータの 数と測定ブラッグ反射数の比から言って, 中性子 だけで行うのには無理があった。そこで, X 線回 折で決めた酸素, 窒素, 炭素, リン, ナトリウム 原子の位置加出発して, 水素原子の位置を決定 するという手法が取られている。これは,まさに,

「相補的使用法」である。中性子の強度が 10 倍あ れば, 中性子だけで完全に構造解析可能であるが, 現時点ではこのようにX線と組み合わせるのが現

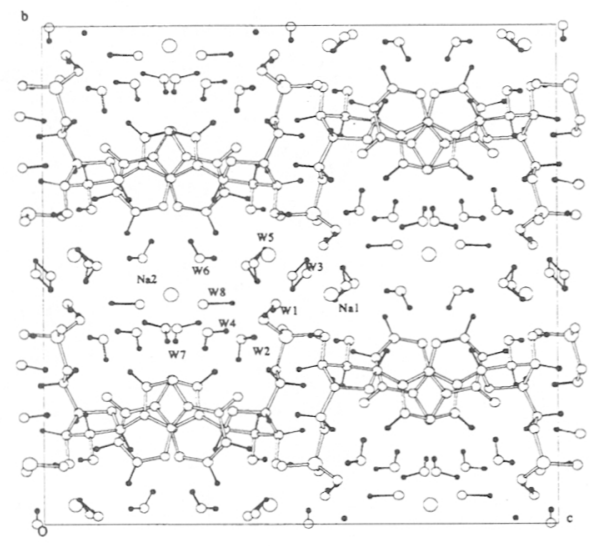

図 2 北里大菅原グループによるイノシン酸 5'-リ ン酸ナトリウムの構造解析の結果. 文献 4 より転 載.

赛的である。 $a$ 面投影の構造を図 2 に示す，具体 的な内容はそのうちに論文が出ると思うので，こ こではいかに複雑かだけを見てもらいたい。

中性子とX線を本当の意味で相補的に使用した 例として, 水素結合型誘電体の例を次に示す。有 機物の Me-HPLN の構造相転移の研究である.こ の物質は 5-methyl-9hydroxyphenalenone と呼ばれ る有機物だが，水素結合が分子内に孤立していて 物理的に見て大変簡単なのに多彩な構造相転移や 大きな同位元素効果を示したりする．分子式は $\mathrm{C}_{14} \mathrm{O}_{2} \mathrm{H}_{14}$ でたくさんの水素原子を含んでいる。今 回の実験では重水素に置換していない.なぜなら， $\mathrm{H}$ と D の違いを見ることも重要な目的だからであ る.試料の大きさは $1.0 \times 1.2 \times 5.2 \mathrm{~mm}^{3}$ の針状結晶で, 中性子をやっている人には驚異的に小さな結晶で あり, X 線をやっている人にとっては驚異的に大 きな結晶である。実験は中性子で核密度分布を求 め, X 線で電子密度分布を求めた。

空間群は $C 2 / c$ で単斜晶系である.まずこのよう な場合, FONDER でどの程度格子定数が決まるの かを示す. $a=12.228(3), b=11.192(3), c=7.331(3)$, $\alpha=90.04(3), \quad \beta=95.05(3), \quad \gamma=90.01(2)$ と得られた。 $\alpha$ とy が 90からずれているが, 十分に誤差の内 で $90^{\circ}$ である. 室温で 430 個の反射を使い, 水素 の温度因子は等方として 95 個のパラメータを決
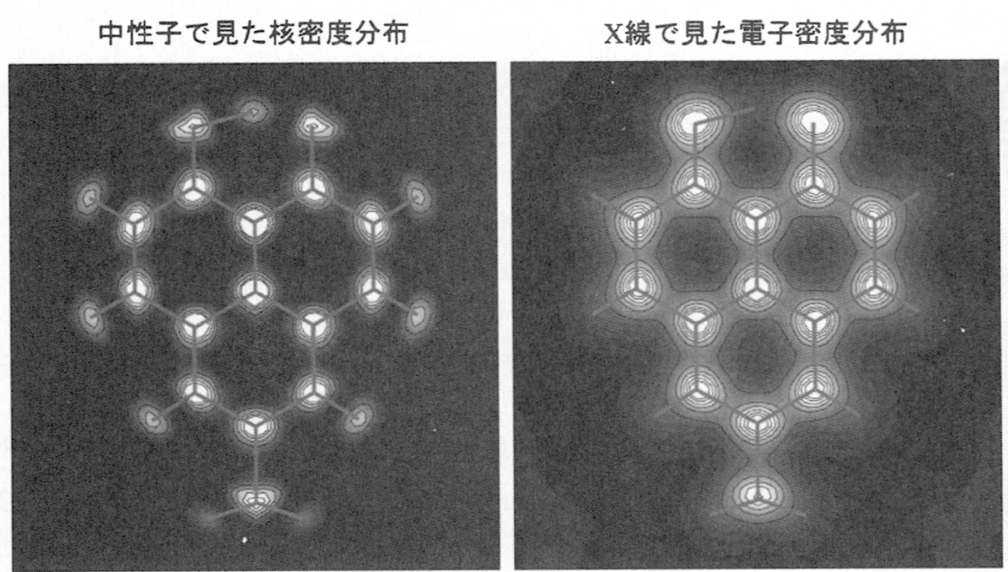

X線で見た差電子密度分布

図 3 MeHPLN の中性子で求めた核密度分布とX 線で求めた電子密度分布

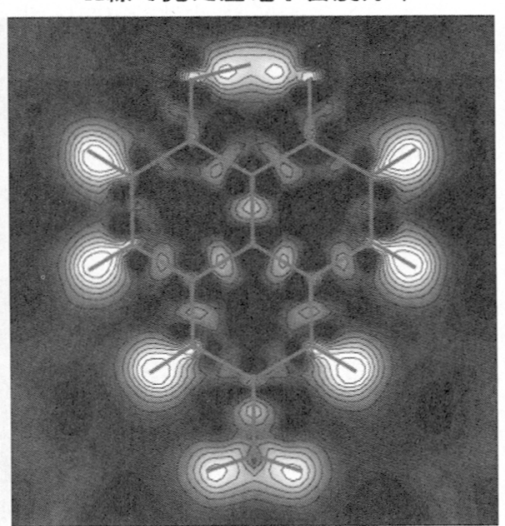


定し，R=7.0\%となった。中性子とは別に，実験室 の $\mathrm{X}$ 線でも構造解析を行っている。密度分布を MEM 法と差 MEM 法で求めた. $\mathrm{X}$ 線で求めた電子 分布 (図 3 の右と中) と中性子で求めた核分布（図 3 の左）を比較すると，水素結合中の水素原子の 分布だけが原子核と電子雲で有意にずれている 5,6). これは, 水素結合の本質が水素原子の電子分 極であることを示している。この電子分極の大き さを実験結果から見積もると, 様々な強誘電体が 持つ自発分極とほとんど同じ大きさになる。した がって，水素結合というのは，かなり大きな電子 分極が関与した結合形態だと言うことが，原子核 と電子雲の分布測定からいえることとなった。こ のような研究は, 中性子と X 線を両方使わないと 決してできることではない。この物質は，低温で 相転移するが，その時に，水素結合中の水素原子 の秩序化とメチル基の回転に関する秩序化と分子 面の回転変位が起こることが，やはり中性子とX 線の低温での構造解析から明らかになった。これ ら 3 つの自由度は全て波として表現できることも 構造解析の結果は示している。

構造解析の最後の例として, $\mathrm{MnF}_{2}$ の結晶構造と 磁気構造解析の結果を示す ${ }^{7)}$.これは, FONDER の開発の初期段階で 4 年生の卒業研究として行っ たものである。試料は $2.5 \mathrm{~mm}$ 角に整形して使用し た.この物質の結晶構造も磁気構造も良く分かつ ているから, 練習問題として行ったものである. スピンの大きさが $S=5 / 2$ だから, 磁気散乱の強度 が強いこともこの物質を選んだ理由である。構造 は，Mnだけを見るとbctで，低温で原点の Mn と 体心の Mn のスピンが反平行になる反強磁性相転 移を行うが，F 原子があるために bct ではなく基 本格子となり，磁気反射は超格子ではなくブラッ グ点にでる， $T_{\mathrm{N}}=70 \mathrm{~K}$ で磁気相転移をする。

図 4 は, $T>T_{\mathrm{N}}$ での結晶構造解析の結果である。 横軸が計算された強度で縦軸が測定された強度で ある. 44 点の反射点で, パラメータ 12 個の構造 解析を行い，消衰効果の補正をしたのが黒丸で消 衰効果の補正をしなかったのが白四角である。い かに消衰效果がきいているかが分かると思う。中

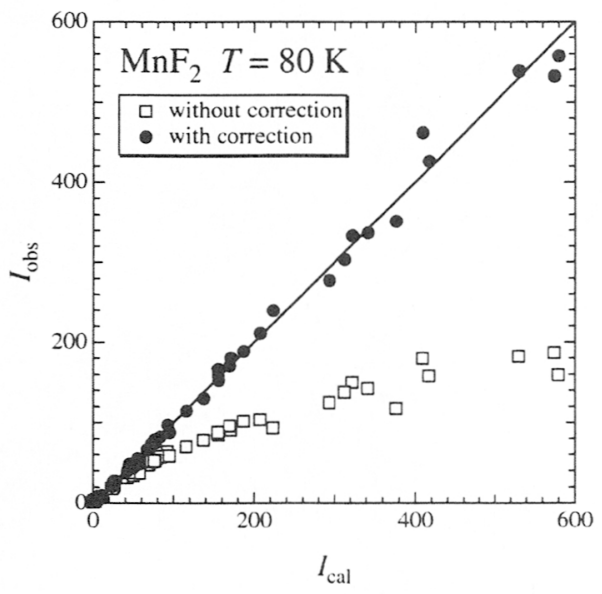

図 $4 \mathrm{MnF}_{2}$ 散乱強度の計算值と測定值の比較
性子単結晶の構造解析では, 無機結晶の時にはお おむねこの程度の消衰効果がある、酸化物などで 結晶性がよいとさらに大きな消衰効果を示すこと もある.図 1 の $\mathrm{NaCl}$ のように結晶性を人工的に 悪くして消衰効果を減らすことも可能だが，通常 は結晶の外形がサイコロ状か円柱状にして, 素直 な補正ですむようにして実験する。消衰効果の補 正は, 結晶中の散乱距離を求めれば（外形から計 算で出す),ただ 1 個のパラメータを決めるだけで すむ. 図 4 の $\mathrm{MnF}_{2}$ の場合, $R=1.77 \%$ と非常に良く 構造が求まっている。

反強磁性相の $7 \mathrm{~K}$ でも構造解析を行った。ここ からは, 演習問題だから行えることである.まず, 核散乱しか出さない反射 33 個 (磁気構造が分かっ ているからできる) を使用して結晶構造解析を行 った。 $R=1.90 \%$ と求まった。これで, スケール因 子と消衰効果のパラメータが求まったので, 磁気 散乱の入った実験で得られた反射の構造因子 $F_{\text {obs }}$ の絶対值を出すことができる。この点が非常に重 要であって, 反強磁性の磁気構造としてまったく パラメータなしに磁気構造因子の実験值と計算值 を求めることが可能である。パラメータなしにも 関わらず $R=6.4 \%$ となった。磁気反射の計算には丸 い磁気形状因子を使用した。もちろん，スピンを 担っている電子の温度因子や $S$ の大きさ, $g$-因子 をパラメータして構造解析することも可能である パラメータの数は 12 (結晶構造として7, 磁気構 造として 3, スケールと消衰効果で 2) となり, $R=3.39 \%$ となった。この場合の計算と測定値の $F$ の比較は文献2の図 13 に出ているので参考にして もらいたい。実験的に得られた $F_{\mathrm{obs}}$ から原子核密 度（図 5 の下） やスピン電子密度（図 5 の上）を 求めることができる。得られたスピン密度（電子 密度）の結果は，確かに少し歪んだ形をしている が，5 個も電子がいるとかなり丸く見えるので， それほど異方的ではない。この手法は，磁性を担 っている電子だけを選択的に見ていることと， 3 次元の軌道の様子を直接見ることができる特徴が

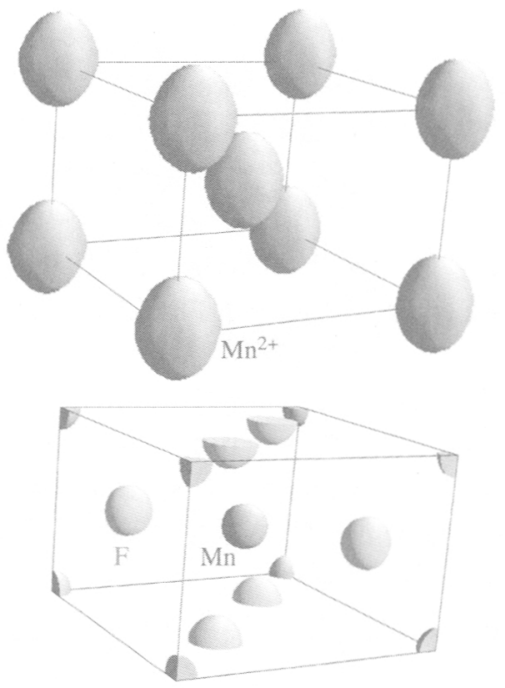

図 $5 \mathrm{MnF}_{2}$ のスピンを担っている電子の密度分 布(上) と核密度分布(下). 
あり,これからさらに磨きをかけていけば，軌道 秩序の問題にも大きな威力を発揮するものと思わ れる. また, よく行われるように, 磁気形状因子 を実験的に求めることももちろん可能である.こ の時にも, 磁気構造因子が絶対值として求まるこ とに注意してもらいたい，結果はここでは示さな いが，明らかにに計算值と実験值が合わない磁気 反射がある。これらは，Mnの $d$-電子の軌道が丸 くないためにでている可能性があるが，この点は さらに装置の信頼度を上げた上で議論が必要であ る.

磁気構造解析としては, 非常に複雑な $\mathrm{YMn}_{2} \mathrm{O}_{5}$ の磁気構造と結晶構造を解いた例もあり, FONDER の能力としては, $S=5 / 2$ のケースでは問 題なく実施可能である. 最近では， $S=1 / 2$ の強度 が弱い難しい実験を行うユーザーも増えてきてお り，モノクロメータの開発とともに，さらなるレ ベルへと FONDER の調整・開発中である. 結晶構 造解析や磁気構造解析に興味ある方は期待しても らいたい.

\section{4 おわりに}

この特集では，X 線と中性子の「相補性」とと もに「優位性」も議論されている.しかしながら， この記事で理解して頂いたように，必ずしも「優 位性」にこだわる必要はないのではないかと思え る.もちろん, 得手不得手があるので，それぞれ の実験が何を見ているかを十分に理解して使い分 ければよいわけで, 決して「中性子で電荷秩序を 直接見た」などというような正体不明の発表が無 いようにしてもらいたいものである.

ここで示したいくつかの結果は, 多くの共同研 究者と行ったものであるが，それぞれは参考文献 の著者を見ていただくこととして，最後にこれら の方々に感謝したい. なお，FONDER の建設は科 学研究費 (研究課題番号 09354004 代表: 野田幸男) と物性研との協力により行ったものである.また, 実験は物性研共同利用の採択課題により行われた ものである.

\section{参考文献}

1) 野田幸男; 日本放射光学会誌, 11(1998)3.

2）野田幸男，木村宏之; 日本中性子科学会「波紋」 11 No.2(2001)8.

3) Y. Noda, H. Kimura, R. Kiyanagi, A. Kojima, Y. Morii, N. Minakawa and N. Takesue; J. Phys. Soc. Jpn. 70 (2001) Suppl. pp.456.

4）山村滋典，長村寛文，菅原洋子，木村宏之，野田幸 男; 日本結晶学会概要集 OC-II-01(2002.12.12).

5) Y. Noda, R. Kiyanagi, H. Kimura, M. Watanabe, A. Kojima, T. Hayaside, T. Mochida and T. Sugawara; Ferroelectrics 269(2002)327.

6) 鬼柳亮嗣; 東北大学大学院理学研究科修士論文 (2002.3).

7) Y. Noda, H. Kimura, S. Komiyama, R. Kiyanagi, A. Kojima, I. Yamada, Y. Morii, N. Minakawa and N. Takesue ; 